\title{
AN ANALYSIS OF THE SINGAPOREAN PREPARATION FOR THE FUTURE WORKFORCE AND RECOMMENDATIONS FOR VIETNAM
}

\author{
Nguyen Thi Hanh Quyen* \\ Center for Vietnam Science and Technology Internationalization Promotion, \\ Ministry of Science and Technology \\ 39 Tran Hung Dao, Hoan Kiem, Hanoi, Vietnam \\ Received 16 May 2019 \\ Revised 15 June 2019; Accepted 27 July 2019
}

\begin{abstract}
This paper aims at firstly reviewing initiatives on workforce transformation in the Industrial Revolution 4.0 funded by the Government of Singapore, and then making recommendations to policy makers regarding the workforce preparation in Vietnam. In the era of continuous change, workforce is a key factor in a thriving economy, thus Singapore's strategy is to engender a future-ready generation for a better Singapore by strengthening the talent pools through lifelong learning and enabling all Singaporeans to excel and discover opportunities to fulfill their potentials. How has Singapore been doing to prepare a tomorrow's workforce? How does Vietnam learn from Singapore's experience in preparing for a future-ready workforce? This analysis will answer those two questions. The findings indicate that (i) the Government of Singapore has adopted an inclusive approach and has succeeded in developing a sustainable skills ecosystem and lifelong learning programs, and (ii) it is necessary for Vietnam to think about our own strategy that will focus on changing public awareness of lifelong learning and skills upgrading, identifying necessary skills for the future workforce, and creating effective action programs to encourage individuals to learn for life, pursue skills mastery and develop fulfilling careers.
\end{abstract}

Keywords: future workforce, lifelong learning, skills mastery, industry 4.0, Singapore, Vietnam

\section{Introduction}

It is pretty obvious that Industry 4.0 or Industrial Revolution 4.0 (IR 4.0) is present everywhere. It is not just a forecast; it is existing and has great impact on human labour and jobs market. In essence, IR 4.0 is a higher level of automation and interconnectivity, which means that sensors, machines, workpieces, and information technology (IT) systems are connected along the value chain. Smart machines collaborate with workers on the assembly line; smart transport systems transfer goods from one place to another; and

\footnotetext{
* Tel.: 84-969030772
}

Email: nthquyen@most.gov.vn smart devices gather and analyze real-time data. As a result, IR 4.0, on the one hand, will enable faster, more flexible and more efficient processes to produce higher-quality goods at reduced costs. On the other hand, it will modify the profile of work, digitalize the workplace and cause employees to face a challenge in keeping up with the industry (The World Economic Forum, 2018). It is evident that workers will need to acquire different and all new sets of skills relevant to the future, such as flexibility, adaptability, innovation, ICT and digital skills, etc. However, persuading workers that they need to upgrade skills when they are busy working is an uphill task. Pushing companies to allow their workers to participate in training classes 
when they are facing challenges themselves is equally hard.

Singapore has addressed these challenges by developing a culture of continuous training and learning (Lim, 2019). Singapore wants to develop a new social culture in which every Singaporean gets satisfaction in life from learning at every stage, from mastering skills, and from being part of a community of learners because the Government of Singapore believes that the contribution of every individual will drive Singapore's next phase of development towards an advanced and highly competitive economy (Committee on the Future Economy, 2017). Deputy Prime Minister Tharman Shanmugaratnam stated that Singapore's future must be about mastery of skills, in every job, and enabling every Singaporean to develop themselves to the fullest (Tay, 2014, as cited in Tharman, 2014). Although the concept of lifelong learning is not new, Singapore's approach is sustainable, pragmatic and rational (Kumar, 2006). This approach involves a broader array of policy instruments and targets a wider range of beneficiaries in a longer term period (Teng, 2016). In Singapore, two statutory boards, SkillsFuture Singapore (SSG) and Workforce Singapore (WSG), were established to identify necessary skills for future jobs, equip Singaporeans with deep skills, and simultaneously build stronger, sustained links between education and employment (Tham, 2018a). With the introduction of a national movement to nurture lifelong learners, SkillsFuture, more and more Singaporeans have changed their mindset and have voluntarily picked up new skills. For example, the first year of the SkillsFuture Credit scheme, which belongs to SkillsFuture initiatives, witnessed 126,000 Singaporeans benefitting from it. They learnt a diverse range of skills - from baking bread to developing mobile applications; IT was the most popular course category across ages (Yang, 2017). SkillsFuture also creates a significant synergy with Singapore's existing higher education and vocational training system (Woo, 2017). Singapore's universities, polytechnics and the Institute of Technical Education have adapted to new scheme of lifelong learning by delivering short modules on emerging areas of growth for busy working adults (Sin, 2017) or courses free of charge as part of the university's efforts to encourage Singaporeans to upskill (Leow, 2017); tertiary curriculum focuses on graduates' long term careers rather than being pigeonholed by degree subjects (Koh, 2018). More importantly, this scheme increases the number of employers engaging in workforce training (Tham, 2018a) by providing grants to cover training expenses (Teng, 2019). Enterprises got more financial support for training employees; the grant worthed up to $\mathrm{S} \$ 10,000$ for each firm can be used to cover 70 per cent of out-of-pocket training expenses (Teng, 2019). A total of 12,000 enterprises took up various SkillsFuture training subsidies in 2018 (Seow, 2019). Obviously, IR 4.0 is affecting every economy around the world and the nature of work is changing with unpredictable growth. Every economy has the same problems regarding future workforce. But Singapore has solved their challenges much more systematically than most countries, in a very deliberate fashion. There is no other country with as deliberate a strategy as SkillsFuture (Tharman, 2018b).

Meanwhile in Vietnam, the workforce remains weak in design, creativity, and productivity. Vietnam is seen as one of the countries with lowest labour productivity in the region (ILO, 2019). Low wage costs are being one of the factors making Vietnam an attractive destination to foreign investors. However, in the era of IR 4.0, robots will 
replace unproductive workers (Shewan, 2017), so low wage costs will be no longer an advantage. This competitive edge, conversely, will threaten the Vietnamese economy prospect. Improving flexibly a skilled workforce is becoming the first and foremost policy to be researched and implemented right now so that Vietnamese economy will be able to stay relevant and keep developing in the IR4.0 (ILO, 2018). Unfortunately, the Vietnam 2035 report did not mention any policy or prospects for tomorrow's workforce. It means that the Government of Vietnam is not really ready for this preparation. Similarly, Vietnamese people are unwilling to acknowledge and adapt to new future jobs. Areport of PricewaterhouseCoopers (PwC) on Industry 4.0 Vietnam found that most Vietnamese respondents had limited knowledge or were unclear of the exact impacts of IR 4.0 ( $27 \%$ of respondents fully understood Industry 4.0 concept and its impacts versus $73 \%$ having limited or no knowledge, or were unclear of the impacts of IR4.0) (PWC, 2018, p.3). The report also illustrated that Vietnam was facing a lack of clarity in the workforce of the specifically required skills to succeed (only 14\% of respondents believed that they and their employees had a clear view of the skills required for digital transformation; 16\% indicated that they had no idea at all on the skills and capabilities required; and the large majority of $70 \%$ fell in between the extremes in their understanding of required skills) (PWC, 2018, p.6). Therefore, an analysis of Singapore's strategies and action programs for future workforce development will benefit Vietnam.

The purpose of this paper is toreview and analyse Singapore's approaches towards workforce preparation for IR 4.0 and to make recommendations for policy makers of Vietnam. Accordingly, the paper attempts to answer two main questions as follows:
1. How has Singapore been doing to prepare a tomorrow's workforce?

2. How does Vietnam learn from Singapore's experience in preparing for a future-ready workforce?

It should be noted here that studying tomorrow's workforce preparation for IR 4.0 is new, even in developed economies. The Government of Vietnam has not published any strategy or framework involving this topic. Hence, the findings from this paper will insipre further research and discussions related to improving human resources in IR 4.0.

\section{Methodology}

The method utilized to conduct this study is document analysis combining with consulting experts in digital learning and workforce preparation in Singapore. The experts are teachers of the training course on Industry Revolution 4.0, which was held by Vietnam Singapore Cooperation Center under the Singapore Cooperation Program in Vietnam in April 2019. Qualitative data were compiled and analysed through the training course materials and other written documents containing information about Singapore's policy, strategy and programs for future workforce development.

The title of the training course is Industry Revolution 4.0 and its impact on policy formulation which aims to providing basic knowlwdege of IR 4.0 and experience of Singapore in preparation for the industrial revolution. In the training course, Vietnamese government officials were introduced manpower programs of Singapore like SkillsFuture or Workforce Singapore- WSG, what they are and how they work. The learners also had opportunities to experience digital learning and design their own lessons on the online e-learing portal. 
The course was instructed by two experts. One person collaborated on a communityled learning initiative funded by the Lifelong learning Council and supported by Skills Future Singapore while the other conducted a study on Singapore's future mobility system. To understand more clearly lifelong learning programs, two catagories of questions were asked and answed by two experts. The first category was about the process such as how Singapore planned for future workforce development, what skills were identified to be important for the future, what matters prevented Singaporeans from pursuing lifelong learning and skills mastery, etc.The second category focused on SkillsFuture such as what outstanding features of lifelong learning in Singapore were, why lifelong learning and SkillsFuture were necessary for developing future workforce in Singapore, how the Government of Singapore designed initiatives for SkillsFuture, what the outcomes of the SkillsFuture were, etc.

Research materials are collected from secondary data including reports, researches and articles on experience of Singapore to prepare for future workforce and existing problems of Vietnamese employment. The research materials are selected over the period from 2016 to 2018 to get updated information.

\section{Preparation for the future workforce in Singapore}

This section will answer the first question "How has Singapore been doing to prepare a tomorrow's workforce?". Being aware of the rapidly transforming employment, the Government of Singapore has created a radical strategy with a clearly economic objective of building a future based on skills. The strategy started from identifying fundamental skills needed for IR 4.0, building industry transformation maps for prioritized domains that Singapore had competitive advantages or important national needs. Then, an initiative called SkillsFuture was launched. Now SkillsFuture, with core values of lifelong learning and skills mastery, is considered a successful model in Singapore. The initiatives of SkillsFuture are clear, holistic, effective, and easy to apply. Meanwhile, ostacles of socializing lifelong learning in Singapore are similar ones that are taking place in Vietnam now. So, SkillsFuture initiatives which have tackled these obscles successfully in Singapore will probably feasible in the case of Vietnam.

\subsection{Identifying fundamental skills needed in IR 4.0}

The Government identifies fundamental skills needed for the new era. It consists of three types of fundamental skills, namely life and career skills, learning and innovation skills, and ICT and digital media skills.

Firstly, life and career skills are soft skills that focus on qualities of flexibility, adaptability, taking initiatives, self-regulating, and social interaction. Traditional job scope is defined by project requirements and deadlines. Workers just focus on their own roles, complete their tasks on hand, and then report to their supervisors daily/ weekly or monthly. They also interact solely with their teammates; and they work within their own cubicles without obligation to socialize with the rest of their organizations. By contrast, IR 4.0 will change the future work environment. Everything will change faster and be unpredictable; customers will request to feedback as soon as possible; 3D printing will enforce designers to have highly-complex skills; big data will lead to skills of detecting patterns, trends and relationships in data sets, and then mining information to predict customer behaviours, 
business risks and opportunities. Future workers, consequently, must be able to work across job functions, wear multiple hats, meet deadlines daily, tackle the improvement on top of their existing roles, and attract others who can work together to get involved. Social interaction and relationships will be considered principal keys to get things done faster and better.

Secondly, learning and innovation skills require critical thinking, problem solving, proactive approach, and creative thinking. Traditionally, job is to do based on extremely well-defined scopes so that workers are not required to be creative and solve problems by themselves. They can ask for favours from their colleagues and their supervisors. However, working in the digital workplace, workers will share their work with robots and be the final decision makers. They will have to figure out problems on their own whether they fall within their domain or not. They must learn to rationalize, analyze, evaluate, and interpret information to make informed judgments as well. Having good attitudes to proactive approach and creative thinking will give future workers a huge advantage.

Finally, ICT and digital media skills are hard skills. Smart factories and smart offices will require future workers to have ICT and digital literacy which includes basic use of technology, IT security and safety, analytics fundamentals, etc.

\subsection{Singapore's approaches towards training workers for the future}

In the era of IR 4.0, it is easy to see unexpected changes in the global order, which may portend significant geopolitical and economic discontinuities. Anew world of work is being created and jobs are being redesigned. It will create a number of new jobs, but will make more jobs redundant so quickly. The
Government of Singapore are aware that they need to form major policies and strategies for training and retraining workers with a strong statement that whichever way the world goes, a small, open economy like Singapore will need to adapt (Singapore's Committee on the Future Economy, 2017, p.2).

Singapore's Government has adopted approaches to jobs and training to prepare Singaporeans and Singapore for the future economy as follows:

\section{(i) Changing mindset}

It is difficult to form encouraging policies for retraining workers because workers and employers may not be aware of the changes which are coming or may not know how these changes would affect them.

The National Trades Union Congress's (NTUC) conducted a survey in Singapore and found that the common responses from workers and employers when they were asked to upgrade skills and retrain are (1) "Why should I change?", (2) "It is up to someone else (worker/ company/Government) to take care of training needs.", (3) "I am already in my 40-50s, there is no need to change.", (4) "I don't know how to go about future-skilling.", (5) "The company already has training programmes in place but the workers are not going for training.", (6) "Where is the budget?", (7) "Where is the time?", (8) "There is no one to cover my work duties for me to go for training.", (9) "I need to take care of my family after work, I have no time.", (10) "Will my employer recognise my efforts to upskill myself?", (11) "It is easier to hire new workers than train existing worker" (The National Trades Union Congress, 2017, pp. 5-10).

NTUC, hence, proposed a framework for collaborative action to change mindsets towards upgrading skills (see Figure 1). It is working effectively and encouraging 
more and more stakeholders to participate in lifelong learning and skills mastery. It is tight collaboration between stakeholders, including union leaders, working people, employers, managers, human resources practitioners, institutes of higher learning, training providers, consultancies, government bodies, and sector agencies. Stakeholders worked together to identify key challenges which they faced in future-proofing workforce in the midst of changing jobs and skills. The framework includes six steps, namely addressing information asymmetry, raising level of awareness, inspiring action, providing holistic support, creating a positive feedback loop, and developing change-agent mentality. All steps direct towards solving the underlying factors belying the mindset challenge related to future-skilling.

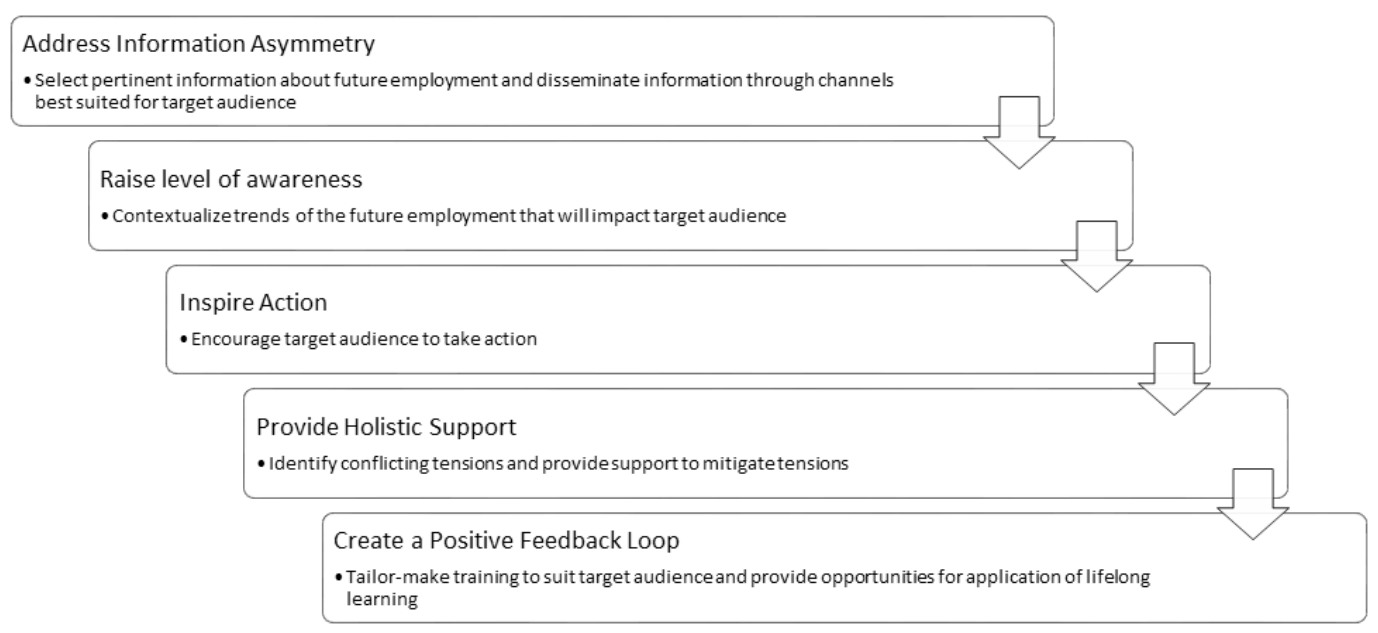

Figure 1. The proposed framework to change mindsets towards upgrading skills(National Trades Union Congress, 2017, p.11)

(ii) Building a tight connection between school and work

The relationship between education and employment used to be more straightforward, study hard in one's early life to get a good job later. However, with a rapid change of technology, knowledge and skills are sometimes made obsolete soon after they are acquired, and lifelong learning and training now become increasingly important. It means that workers need to update their skills over and over again throughout their career while companies need to invest more in training.

SSG and WSG aim to sustain link between education and employment and build it stronger. SSG helps to maximise Singaporean potentials and develop their skills with initiatives of learning as a way of life and mastery of skills. WSG enables individuals to adapt to new jobs and employers to transform into new industries. Both these statutory boards share the portal https://www.ssg-wsg. gov.sg/ so that employees can easily access necessary skills and supports for their current and future jobs.

(iii) Helping workers to upskill and reskill

In working environments where disruption affects the various sectors unevenly, measures to help workers need to be more "targeted and surgical" (Tham, 2018b). In Singapore, the Government is moving towards more targeted programmes that allow for some customisation to address the needs of workers and companies in different 
sectors. It means that the Government is implementing action programs to help workers to upskill and reskill.

Upskill is to teach someone additional skills to enhance his/her abilities within the same job profile and therefore significantly amplifies his/her value within the company. Meanwhile, reskill is to improve the collective skill set of workers. The re-skilling process involves learning new technology or retraining in the skills needed by a particular company and be able to utilise these skills into an entirely different role within that company.

The missions of reskilling and upskilling are developed by SSG-WSG with various training programs right for every Singaporean at every stage of working life. For example, WSG has launched Professional Conversion Programmes that help professionals prepare for new jobs in the new economy, even within the same company.

(iv) Shifting culture

SkillsFuture is creating a strong culture of lifelong learning and skills mastery (Tan, 2016). The Government encourages learning as a way of life, regardless of age or education while all Singaporeans actively participate in developing their fullest potentials throughout life, regardless of their starting points. That is a shift in societal culture. Through this movement, the skills, passion and contributions of every individual will drive Singapore's next phase of development towards an advanced economy and inclusive society.

\subsection{Industry Transformation Maps}

Singapore is positioned as a key node for technology, innovation and enterprise in Asia and around the world, so the Government first launched as part of a $\$ \$ 4.5$ billion industry transformation program (Industry Transformation Maps - ITMs) at Budget 2016 (Min, 2018). The program integrated crosscutting solutions and an industry-focused approach to address issues and deepen partnerships between the Government, firms, industries, trade associations and chambers (Ministry of Trade and Industry, 2017). Under ITMs, 23 industries are grouped into 6 clusters including manufacturing, built environment, trade and connectivity, essential domestic services, modern services, and lifestyle. Those industries together cover about $80 \%$ of Singapore's GDP (Min, 2018). Each ITM integrates productivity movement, skills development, innovation and internationalization. Jobs and skills of each ITM will support SSG-WSG to design skills programs which are suitable for the development strategy of each industry.

For example, the ITM for precision engineering predicts 3,000 new jobs for professionals, executive, managers and technicians (PMETs) in the precision engineering sector to come online by 2020 (Hui, 2016). IR 4.0 will shift the industry into new growth areas such as additive manufacturing, robotics, advanced materials, sensors and lasers and optics so that demands for precision engineers will increase. Under the roadmap for the precision engineering industry, it is crucial to equip workers to take on these new roles for precision engineering industry. Training programs for SkillsFuture will be designed to meet the future demands.

\subsection{Skills development programs}

Singapore's strategy for workforce improvement is to benefit everyone no matter where he/she is in life - schooling years, early career, mid-career or silver years. Based on the identification of fundamental skills needed in IR 4.0 and ITMs, the Government of Singapore introduced SkillsFuture to help Singaporeans get ready for new career opportunities instead of feeling scared of manpower challenges of the innovative businesses. SkillsFuture scheme comprises 
a broader array of programs that meet requirements and develop all Singaporeans and attract participation of varieties of stakeholders. The programs are categorized into 5 levels of subjects, namely programs for students, for early-career employees, for midcareer employees, employers, and training providers (see Figure 2).

For students, programs, like enhanced internship, work-learn bootcamp, etc., intend to provide a full system of guidance to help them make well-informed choices in education, training, and careers. They also get benefits from internship or on-the-job training.

For new employees in the early phases of career, the programs provide updated knowledge and skills related to occupations and industries to make them stay relevant to the new economy of digitalization, internationalization, and innovation. They will also receive credits to pay for their wanted training courses.

For mid-career employees, the initiatives mainly encourage them to upskill or even reskill by awards, fellowships or subsidies. There are a number of very short courses for their choice like a two-day program in the SkillsFuture for Digital Workplace.

For employers, the programs aim to promoting employer recognition and support them to organize training courses based on skills and mastery. Employers will get benefits as they participate in the SkillsFuture initiatives. For instance, they will be honored for their significant efforts in investing in workforce training in the SkillsFuture Employer Awards.

For training providers, the key importance is to boost the collaboration between them and other stakeholders like learners, companies, and the Government. SkillsFuture designed programs like SkillsFuture Series, SkillsFuture Credit, Skills Framework, SkillsFuture MidCareer Enhanced Subsidy Training and Adult Education Sector Transformation Plan to benefit training providers but stimulate them to interact closer with other stakeholders.

\begin{tabular}{|c|c|c|c|c|}
\hline 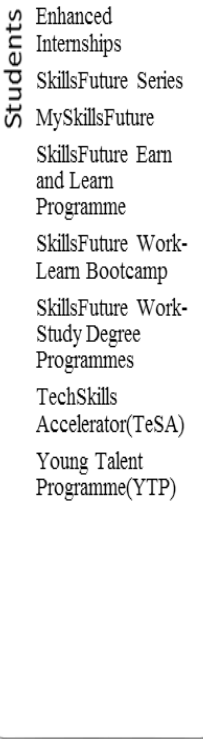 & 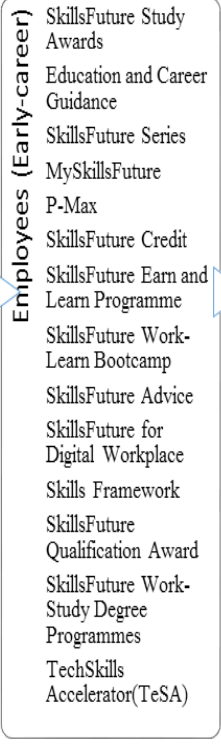 & 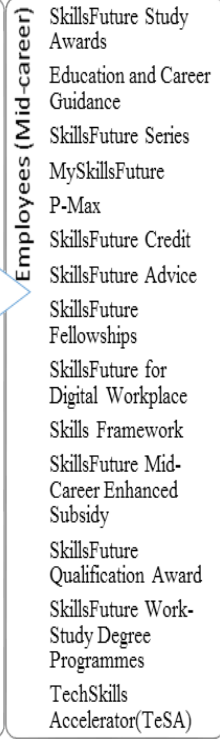 & 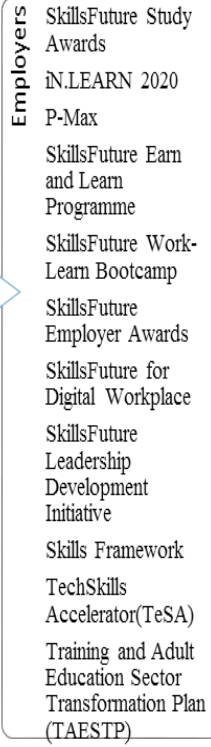 & 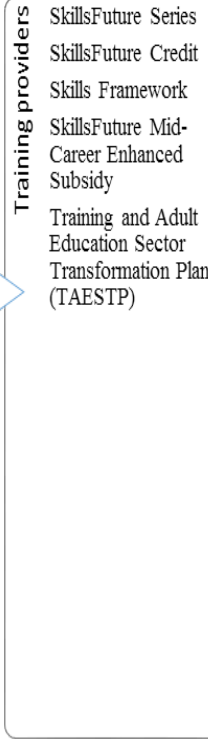 \\
\hline
\end{tabular}

Figure 2.Categories of SkillsFuture programs (divided according to beneficiaries)(compiling from SkillsFuture's website) 
This paper will list the ongoing skills development programs in details.

(i) Enhanced Internships: The programs are for second- or third-year students enrolled at the polytechnics and the Institute of Technical Education (ITE) with the aim of helping them make better career choices through real-world exposure to the industries and enabling them to make a better transition into the workplace. The Enhanced Internships are a component of full-time diploma courses with a greater level of company involvement in developing and mentoring interns.

(ii) SkillsFuture Series: They are industryrelevant training programmes that focus on emerging skills for every Singaporean with 3 proficiency levels of Basic, Intermediate and Advanced. At the starting stage, 8 emerging areas are selected, namely data analytics, finance, tech-enabled services, digital media, cyber security, entrepreneurship, advanced manufacturing, and urban solutions. Participants get $70 \%$ subsidy on course fees.

(iii) MySkillsFuture: This is a one-stop online portal that allows Singaporeans of all ages to access to industry information and tools to search for training programmes to broaden and deepen skills. Singaporeans get benefits from online assessment tools to understand themselves better, latest industry information and upskilling tips, and create their own learning journey based on their career and learning needs.

(iv) SkillsFuture Earn and Learn Program: This is a work-learn programme for fresh graduates who are within three years of either graduation from the Institute of Technical Education (ITE) and polytechnics or the Operationally Ready Date for National Servicemen. It is also for companies, societies and non-profit organisations that are registered or incorporated in Singapore. In essence,
SkillsFuture Earn and Learn Programmes are designed to push collaboration with industry and to ensure relevance to employers and the growth of the sector. Since 2015, the program has been introduced in 25 sectors, including Aerospace, Biomedical Sciences, Food Services, Games Development, Healthcare, Hotel, Infocomm Technology and Retail.

For fresh graduates, it provides them with more opportunities to build on the skills and knowledge with industry-recognised qualifications/certification, and better supports their transition into the workforce. They will get a sign-on incentive of $\$ \$ 5,000$ and receive a competitive starting salary and full-time employment with participating companies.

For employers, they can recruit local fresh talents who have relevant skills and aptitude to meet the needs of the company. Participating employers will also receive a grant of up to $\mathrm{S} \$ 15,000$ per individual placed in the SkillsFuture Earn and Learn Programme to defray the costs of developing and providing structured on-job-training and to encourage them to set out career progression pathways.

(v) SkillsFuture Work-Learn Bootcamp (WLB): This is a work-learn programme that gives fresh graduates and mid-career individuals the relevant job-role specific behavioural, mind-set and technical skills in sectors with acute demand. Employers that are registered or incorporated in Singapore can participate in WLB.

For individuals, they undergo 8 to 12 weeks of intensive institutional training before seeking employment. They will have an opportunity to receive a competitive starting salary and full-time employment with participating companies, along with mentorship. Singapore citizens even receive a maximum training allowance of $\$ \$ 500$ per month upon completion of training. 
For companies, they can work more closely with the Polytechnics and ITE in designing a training programme that cater to specific job roles required in the company, recruit more effectively job-ready individuals, and receive a mentorship grant of $\mathrm{S} \$ 5,000$ per individual placed in WLB to provide mentorship for the individual.

(vi) SkillsFuture Work-Study Degree Programmes: the programs equip students with deep technical and essential generic skills and facilitate their transition from universities to workplace after graduation. The programmes are also open to in-employment upgraders. Basically, the curricula integrate institution-based learning with structured on-the-job training and the partnering companies support the development and delivery of the programmes, and assessing students' performance at the workplace. The SkillsFuture Work-Study Degree Programmes will generally be delivered in either of two modes: Term-in/Term-out (students alternate between spending one to two terms (or trimesters) in university and at the workplace) or Work-day/Study-day (students alternate between working three or four days in the partner company, and studying in university for the remaining one or two days each week).

(vii) TechSkills Accelerator (TeSA): This initiative is for information and communications technology (ICT) working professionals (Fresh ICT graduates, existing ICT professionals, and aspiring ICT professionals from both ICT and non-ICT backgrounds) in order to enhance training and placement opportunities for ICT jobs across the economy. TeSA is driven by Infocomm Media Development Authority (IMDA) in partnership with strategic partners such as Workforce Singapore (WSG) and SkillsFuture Singapore (SSG), and in collaboration with industry partners and hiring employers.
For ICT employees: with TeSA, they are facilitated with reskilling or upskilling to meet industry needs.

For employers: They will receive funding support from IMDA, WSG or SSG to implement the respective training programme, employ future-ready ICT professionals, and be able to upskill and deepen the skills of existing employees who are mid-level ICT professionals.

For the Government: TeSA helps them move closer towards achieving Singapore's vision of building a digital economy.

(viii) Young Talent Programme (YTP): This is for Singaporean Students or Singapore Permanent Residents who love to gain overseas work experience. YTP allows them to sign up for overseas internships and work and study programmes in order to prepare their future global careers. They will also receive a subsistence allowance for the duration of the programme.

(ix) SkillsFuture StudyAwards: The awards are for early to mid-career Singaporeans who are committed to developing and deepening their skills in key sectors and have relevant working experience in such sectors. They aim to encourage Singaporeans to upgrade specialist skills needed for future economic growth sectors or in areas of demand. The recipients will receive a monetary award of $\mathrm{S} \$ 5,000$ to defray out-of-pocket expenses associated with the course fees. It can also be used on top of existing Government course fee subsidies. Over 500 study awards are given from October 2015 and up to 2,000 study awards annually at a later stage.

(x) Education and Career Guidance (ECG): ECG is a holistic and experiential effort for Singaporeans from different stages of life e.g. students, adults, individuals at different phases of their careers with the 
aim of helping them make informed career decisions. ECG includes a number of activities from career talks, counselling, to one-to-one career coaching.

For primary, secondary, junior college and centralised institute students: ECG with dedicated counsellors helps them discover their strengths and interests and provides information on industries, occupations, courses and education institutions in Singapore. So they can make informed decisions on what to study, or learn which career might suit their interests, abilities and passions best.

For ITE and Polytechnic students: ECG sets up a minimum of 40-60 hours across two years for ITE students and three years for Polytechnic students. Students engage in ECG-related activities and lessons conducted in the classroom, and participate in outof-classroom activities such as industry immersion programmes, learning journeys and career talks. So they can be well prepared for a smooth transition into the workplace.

For adults: they may access career advisory services through WSG-Careers Connect. New workforce entrants, mid-career switchers or individuals in career transition can benefit from the suite of career matching services that include career advisory, job search workshops and interactive career resources available at Careers Connect. These people may also get one-to-one career coaching, from professionally-certified Career Coaches.

(xi) SkillsFuture Credit: This aims to encourage all Singaporeans aged 25 and above to engage in lifelong learning. The participants will receive an opening credit of $\$ \$ 500$ from January 2016. The credit will not expire and the Government will provide periodic top-ups so that the participants can accumulate their credit. SkillsFuture Credit can also be used on top of existing Government course subsidies to pay for a wide range of approved skillsrelated courses.

(xii) SkillsFuture Advice: This initiative aims to help Singaporeans understand the importance of lifelong learning and how they can tap on to available resources for their career planning and skills upgrading needs. It includes physical workshops and mobile and web learning. The workshops cover advice related to (i) how to be ready for new opportunities amidst a fast changing economy, (ii) how to plan for careers and understand career interests, (iii) what resources to support skills upgrading and career plan. SkillsFuture Singapore partners with Community Development Councils (CDCs), People's Association (PA), Workforce Singapore (WSG) and Employment and Employability Institute (e2i) to provide information through SkillsFuture Advice workshops.

(xiii) SkillsFuture for Digital Workplace: This is a national initiative that aims to prepare all Singaporean adults to become digital ready. This is a two-day programme (up to 18 hours) that will enhance ability to work in a technology-rich environment, to understand and apply cyber security in daily / work applications, and to know how to analyze data.

(xiv) Skills Framework: The Skills Framework is developed for individuals, employers, and training providers to provide up-to-date information on sector, career pathways, occupations/job roles description, skills description, and training programmes for skills upgrading and mastery.

Individuals in their early and/or midcareer can use the Skills Framework to make informed decisions on education and training, career development and skills upgrading based on information provided. 
Employers can use the Skills Framework to design progressive human resource management and talent development plans based on the detailed skills information in the framework.

Training Providers can use the Skills Framework to gain insights into sector trends and skills in demand, which allow them to innovate and contextualise their curricula design and training programmes to suit the needs of the sector.

(xiv) SkillsFuture Qualification Award: This award is for all Singaporean workers to recognize their efforts to attain Workforce Skills Qualifications (WSQ). Singapore Citizens who attain a WSQ full qualification will be eligible for a cash award of $\mathbf{\$} \$ 200$ or $\mathrm{S} \$ 1,000$. WSQ is a national credential system that trains, develops, assesses and certifies skills and competencies for the workforce. WSQ has different levels of qualifications including Certificate, Higher Certificate, Advanced Certificate, Diploma, and Specialist Diploma.

(xvi) SkillsFuture Mid-Career Enhanced Subsidy: It supports and encourages lifelong learning and helps mid-career individuals aged 40 and above stay responsive to a changing workplace. Eligible individuals receive higher subsidies of up to $90 \%$ of course fees for over 8,000 SSG-supported courses from 1 October 2015 , and at least $90 \%$ of programme cost for Ministry of Education (MOE)-subsidised fulltime and part-time courses.

(xvii) SkillsFuture Fellowships: It is patronized by the President of the Republic of Singapore to honour individuals as masters of skills and mentors of future talent, with a monetary award of S\$10,000. The SkillsFuture Fellowships are open to all Singapore Citizens with at least 10 years of working experience in the same (or related) industry or job function. (xviii) iN.LEARN 2020: Innovative Learning 2020 (iN.LEARN 2020) is a learning innovation initiative for all Continuing Education and Training (CET) partners and practitioners (training providers, adult educators, enterprises, consultants and technology vendors) who are interested in using innovation for learning design, development and delivery of blended learning. This initiative aims to push closer collaboration among CET partners and practitioners to enhance the quality, accessibility, and effectiveness of blended learning.

Within working of iN.LEARN, Institute for Adult Learning (IAL) sets up a learning innovation hub called iN.LAB where the CET community can come together to explore, collaborate and contribute to learning innovations. iN.LAB is designed and equipped with facilities, equipment and tools to support experimentation and collaboration on learning innovation. To seed the sharing and exploration of learning innovation, iN.LAB conducts four key events:

- InnovJam - Brainstorming of different learning innovations to improve training delivery and learning experience;

- InnovPlus - Competition of ideas to address learning issues in organisations. Prize money of up to $\mathrm{S} \$ 200,000$ will be awarded to winning ideas for prototype development;

- InnovLogue - Conversation with experts to learn from their experiences;

- Innovbites - Lunch-time quick bites for invited CET partners and practitioners to share tips-and-tricks and insider know-hows on learning innovations.

(xix) P-Max: P-Max is an Place-and-Train $(\mathrm{PnT})$ programs that assist small and medium enterprises (SMEs) to better recruit, train, manage and retain their newly-hired PMETs, encourage the adoption of progressive human 
resource practices within SMEs, and help to place job-seeking PMETs into suitable SME jobs. P-Max is working under four steps of job matching, workshop training, posttraining follow-up, and assistance grant.

- Job Matching: Job-seeking PMETs will be screened and matched with suitable positions in hiring SMEs by Programme
Managers (PMs). SMEs with newly-hired PMETs are also eligible to participate.

- Workshop Training: SME supervisors and their newly-hired PMETs will attend respective SME and PME workshops. Both workshops enjoy up to $90 \%$ SSG course fee funding for Singaporeans, Singapore Permanent Residents, and SMEs.

\begin{tabular}{|c|c|c|c|}
\hline \multicolumn{4}{|c|}{ P- Max } \\
\hline & $\begin{array}{c}\text { Association of Small and Medium } \\
\text { Enterprises Place-and-Train } \\
\text { programme (ASME PnT Programme) }\end{array}$ & \multicolumn{2}{|c|}{$\begin{array}{c}\text { Singapore National Employers } \\
\text { Federation Place-and-Train } \\
\text { programme (SNEF PnT Programme) }\end{array}$} \\
\hline $\begin{array}{c}\text { One-day SME } \\
\text { Workshop }\end{array}$ & $\begin{array}{c}\text { Three-day PMET } \\
\text { Workshop }\end{array}$ & $\begin{array}{c}\text { One-day SME } \\
\text { Workshop }\end{array}$ & $\begin{array}{c}\text { Two-day PMET } \\
\text { Workshop }\end{array}$ \\
\hline $\begin{array}{c}\text { Course Fee } \\
\text { Funding by } \\
\text { WSG }\end{array}$ & \multicolumn{4}{|c}{ Up to 90\% course fee funding } \\
\hline
\end{tabular}

Figure 3. A description of P-Max(P-MAX brochure, 2017)

- Post-Training Follow-up: Upon completion of both workshops, P-Max programme managers will follow up with the newly-trained PMETs and their SME representatives for a period of six months.

- Assistance Grant: SMEs that successfully complete the six-month followup and retain their newly-hired PMET employee(s) will then be eligible for a one-off grant of $\mathrm{S} \$ 5,000$.

(xx) SkillsFuture Employer Awards: It is patronized by the President of the Republic of Singapore to honor employers for their significant efforts in investing in their employees' skills development and their advocacy for SkillsFuture. The Award is open to all Singapore registered entities, including small and medium enterprises (SMEs), corporations, and voluntary welfare organisations with two categories: SkillsFuture Employer Awards for Small and Medium Enterprises (SMEs) and SkillsFuture Employer Awards for Non-SMEs. (xxi) SkillsFuture Leadership Development Initiative (LDI): This initiative aims to develop Singaporean business leaders for the next generation through in-house leadership development programmes. It is eligible for all Singaporeans who are keen to enhance their corporate leadership competencies and for employers who are dedicated to developing the leadership potentials of their Singaporean employees.

\subsection{Outcomes of skills development programs}

Programs involving lifelong learning and skills mastery are increasingly attracting more and more participants. This indicates that the Government of Singapore ispreparing well for future workforce. The detailed description of outcomes are seen in Table 1. 
Table 1. A summary of the outcomes of skills development programs

(Source: summarized from statistics of SkillsFuture Year-in-view in 2016, 2017, 2018)

\begin{tabular}{|c|c|c|c|}
\hline Programs & 2016 & 2017 & 2018 \\
\hline $\begin{array}{l}\text { Enhanced } \\
\text { Internships }\end{array}$ & $\begin{array}{l}\text { about } 290 \\
\text { polytechnic and } \\
\text { ITE courses } \\
\text { offered }\end{array}$ & $\begin{array}{c}\text { by } 90 \% \\
\text { Polytechnic \& ITE Courses } \\
\text { offered }\end{array}$ & $\mathrm{N} / \mathrm{A}$ \\
\hline $\begin{array}{l}\text { SkillsFuture } \\
\text { Series }\end{array}$ & N/A & $\begin{array}{c}\text { Over 2,100 Singaporeans in } \\
8 \text { emerging skills areas }\end{array}$ & $\begin{array}{l}\text { Over } 30,000 \\
\text { Singaporeans }\end{array}$ \\
\hline MySkills Future & N/A & $\begin{array}{c}\text { Over } 1.9 \text { million users visit } \\
\text { and over } 268,000 \text { log-ins } \\
\text { since launch }\end{array}$ & $\begin{array}{l}7.6 \text { million users visit to } \\
\text { MySkillsFuture. }\end{array}$ \\
\hline $\begin{array}{l}\text { SkillsFuture } \\
\text { Earn and Learn } \\
\text { Programme } \\
\end{array}$ & $\begin{array}{l}\text { Total of } 40 \\
\text { programs }\end{array}$ & $\begin{array}{l}76 \text { programs for graduates } \\
\text { from polytechnics and ITE }\end{array}$ & $\begin{array}{l}\text { Over } 100 \text { programs in } \\
35 \text { sectors }\end{array}$ \\
\hline $\begin{array}{l}\text { SkillsFuture Work- } \\
\text { Learn programmes }\end{array}$ & N/A & $\mathrm{N} / \mathrm{A}$ & Over 3,500 participants \\
\hline $\begin{array}{l}\text { SkillsFuture } \\
\text { Work-Study } \\
\text { Degree }\end{array}$ & N/A & $\begin{array}{c}10 \text { skillsfuture work-study } \\
\text { programmes } \\
\text { have been launched }\end{array}$ & About 150 participants \\
\hline $\begin{array}{l}\text { Young Talent } \\
\text { Program }\end{array}$ & $\begin{array}{c}\text { Over } 500 \\
\text { polytechnic and } \\
\text { ITE students } \\
\text { received } \\
\text { funding support } \\
\text { to participate } \\
\text { in overseas } \\
\text { immersion } \\
\text { programs }\end{array}$ & $\begin{array}{l}\text { Over 1,400 Polytechnic } \\
\& \text { ITE students received } \\
\text { funding support to } \\
\text { participate in overseas } \\
\text { immersion programs }\end{array}$ & $\mathrm{N} / \mathrm{A}$ \\
\hline $\begin{array}{c}\text { Skillsfuture Study } \\
\text { Awards }\end{array}$ & $\begin{array}{c}\text { Over } 700 \\
\text { Singaporeans } \\
\text { awarded from } 20 \\
\text { sector agencies } \\
\text { and } 27 \text { areas of } \\
\text { specification }\end{array}$ & $\begin{array}{l}\text { Over 2,400 award recipients } \\
\text { from } 21 \text { sector agencies and } \\
\quad 31 \text { specialised areas }\end{array}$ & $\begin{array}{c}\text { About 3,800 } \\
\text { award recipients }\end{array}$ \\
\hline Skillsfuture Credit & $\begin{array}{c}\text { Utilized by } \\
\text { over } 126,000 \\
\text { Singaporeans and } \\
\text { over } \mathrm{S} \$ 18,000 \\
\text { used for credit }\end{array}$ & $\begin{array}{l}\text { Benefitted over } 285,000 \\
\text { Singaporeans }\end{array}$ & $\begin{array}{c}\text { Utilized by about } \\
431,000 \text { Singaporeans }\end{array}$ \\
\hline $\begin{array}{c}\text { SkillsFuture } \\
\text { Advice }\end{array}$ & $\mathrm{N} / \mathrm{A}$ & $\begin{array}{c}\text { Over 4,600 Singaporeans } \\
\text { attended the workshops } \\
\text { since launch }\end{array}$ & $\begin{array}{c}\text { Over } 52,000 \\
\text { individuals attended } \\
\text { workshops } \\
\end{array}$ \\
\hline
\end{tabular}




\begin{tabular}{|c|c|c|c|}
\hline $\begin{array}{c}\text { SkillsFuture for } \\
\text { Digital Workplace }\end{array}$ & N/A & $\begin{array}{c}\text { Over 4,600 Singaporeans } \\
\text { participated since launch }\end{array}$ & $\begin{array}{c}\text { Over 25,000 } \\
\text { Singaporeans }\end{array}$ \\
\hline Skills Frameworks & $\begin{array}{c}3 \text { frameworks } \\
\text { launched; } 7 \\
\text { frameworks in the } \\
\text { pipeline }\end{array}$ & 14 frameworks rolled out & $\begin{array}{c}25 \text { frameworks rolled } \\
\text { out }\end{array}$ \\
\hline $\begin{array}{c}\text { Skillsfuture Mid- } \\
\text { career Enhanced } \\
\text { Subsidy }\end{array}$ & $\begin{array}{c}\text { About 9,000 } \\
\text { courses are } \\
\text { subsidized for } \\
\text { over 69,000 } \\
\text { Singaporeans }\end{array}$ & Singaporeans subsidized & $\begin{array}{c}\text { About 170,000 } \\
\text { Singaporeans subsidized }\end{array}$ \\
\hline $\begin{array}{c}\text { SkillsFuture } \\
\text { Fellowships }\end{array}$ & N/A & 27 recipients & 56 Recipients \\
\hline $\begin{array}{c}\text { SkillsFuture } \\
\text { Employer Awards }\end{array}$ & N/A & 14 awards & 41 awards \\
\hline
\end{tabular}

\section{Recommendations for Vietnam}

The world of work now is changing quickly and unpredictably with the presence of IR 4.0. It puts challenges on all economies to transform and adapt. The key solution to overcome these challenges is the workforce which will help economies thrive in the future. So, how does Vietnam learn from Singapore's experience in preparing for a future-ready workforce?

The labor productivity of Vietnam is evaluated to be very low in comparative relation with some East Asian and ASEAN countries. A report assessing the competitiveness of countries' human resources showed that Vietnam ranked 92 out of 125 countries (The Adecco Group \& Tata Communications, 2019, p. 212). According to the World Economic Forum (WEF)'s Readiness for the Future of Production Report, Vietnam was ranked 90th in technology and innovation and 70th in human capital, among 100 countries (The World Economic Forum \& A.T. Kearney, 2018, p. 251). It leads to the fact that Vietnam is to be positioned among those that are currently not ready for IR 4.0. So, how can Vietnam catch up with IR 4.0 and take advantages of the industrial revolution? The answer is definitely to shape a future in which people are at the heart of economic growth and social progress. The entire education system must recognize the diversity of strengths and talents of each Vietnamese; and one of the most important goals of education is to nurture talents and encourage lifelong learning needs of learners (Phung, 2018). In other words, it is critical to improve human resources by encouraging Vietnamese people to keep deepening and mastering their skills, knowledge and experience at every stage of life.

The idea of lifelong learning was formally institutionalized in Vietnam in the law on education in 1998 (Education Law, 1998). After that, this concept was stated in the Prime Minister's Decision No. 112/2005/QĐ-TTg to approve the scheme on building a learning society in the period 2005-2010 and in his Decision No. 711/QĐ-TTg approving the 2011-2020 education development strategy. It showed that Vietnam has a supportive legal framework for development of lifelong learning. Vietnam even has launched some lifelong learning centres under the support of UNESCO. However, lifelong learning 
opportunities in Vietnam are limited and develop very slowly due to obstacles like conceptual, institutional, structural, financial, and individual obstacles For example, lifelong learning is conceptually considered as responsibility of only the education sector; many people feel that lifelong learning is not necessary for their careers; universityindustry collaboration is still weak; mid-career professionals are too busy to pursue lifelong learning (Pham, 2014). These were used to be problems of Singapore when they planned to shift onto culture of lifelong learning and skills mastery. So, experience from Singapore should be considered. Singapore's approach focuses on both the mindset and the sources to support continuous learning, reskilling and job replacement in the rapidly changing context.

Firstly, it is essential to raise awareness of lifelong learning and skills upgrading. In 2011, a week of lifelong learning was launched in Hanoi for the first time (UNESCO, 2011) with multiple activities like seminars providing information or mass media promotion to enhance communication. Even though it is a positive activity, it does not tackle the root of the problem. Looking deeper into the problem, Vietnamese learners suffer from a degree-illness (they learn for degrees rather than for skills) while employers are not yet aware the significance of training to reduce cost and increase efficiency (Pham, 2014). Administrators also think that lifelong learning is a matter of training providers. Lifelong learning in Vietnam is based on five pillars, namely formal education, vocational education, distance education, comtinuing education centers, and community learning centers (ASEM LLL Hub \& UNESCO Hanoi, 2010). Singapore's approach is quite different. They claim that the main stakeholders of lifelong learning and mastery skills, in the context of fast-changing employment, are employees (or learners), employers, and training providers. Learners learn what they are interested in and what is suitable for real-world of work. Meanwhile, employers, along with training providers, create the best learning opportunities for their workers. Therefore, the paper recommends for Vietnam regarding awareness as follows:

To begin with, education policy makers should re-emphasize that the subjects of lifelong learning are employees (including both current and future employees), employers, and training providers. Policies should involve or directly deal with the matters of these three groups.

Next, policy makers need to recognize and understand challenges that prevent these groups from investing in learning throughout their life. Specifically, the Government of Vietnam, together with Trade Union conducts a survey to identify key challenges in futureproofing the workforce in the midst of changing jobs and skills. The survey should cover all stakeholders of the economy, including Trade Unions, working people, students, employers, management, human resources practitioners, institutes of higher education, training providers, consultancies, and Government agencies, amongst others.

Besides, the Government should disseminate pertinent information about the changing nature of jobs and skills, negative and positive impacts on employees and employers, commitments of the Government to support lifelong learning, successful stories of lifelong learning, etc. through effective communication channels such as mass media, seminars, conferences, public discussions, etc. For example, Vietnam can apply an initiative of MyskillsFuture, which is a one-stop online portal allowing learners to chart their own 
career and lifelong learning pathways through access to industry information and tools to search for training programs to broaden and deepen skills.

Furthermore, It is necessary for the Government to tidentify necessary skills that will guide Vietnamese workforce to match up with employments of the future. As technological breakthroughs rapidly shift the frontier between the work tasks performed by humans and those performed by machines, global labour markets are undergoing major transformations. Many existing jobs will disappear just in a few coming years. What is being taught at schools will soon become obsolete. These transformations, without good management, will pose the risk of widening skills gaps and will consequently make a number of future employees jobless. The Government of Vietnams should set out industry transformation maps like Singapore in order to examine deeply the industry landscape, the future trends, and what skills need to upgrade. Accordingly, the Government will design accurate roadmaps for mastery skills and lifelong learning for Vietnamese workforce.

Finally, It is necessary for the Government to construct specified action programs that will be a holistic support for all Vietnamese people, companies and training institutions to participate in lifelong learning and skills development. Vietnam can learn from Singapore in dividing target groups into students, early-career workers, mid-career workers, employers, and training providers and then designing appropriate programs for each group. This paper will propose some appropriate programs in the case of Vietnam, for example,

(i) For students, they need to develop their autonomous and independent learning, learn for skills instead of for degree, and learn what interests them. The initiative of Education and Career Guidance (ECG) will probably be helpful for Vietnamese students because it aims at equipping students with the necessary knowledge, skills and values to make informed education and career decisions. The ECG will provide relevant and timely support to individuals at different life stages though ECG Counsellors in small groups or through individual appointments. They will participate in out-of-classroom activities such as industry immersion programmes, learning journeys and career talks to make informed decisions on what to study, or learn which career might suit they best. The SkillsFuture Work-Learn Bootcamp (WLB) is also a good choice. WLB's participation will undergo 8 to 12 weeks of intensive institutional training before seeking employment so that students can understand the relevant job-role specific behavioural, mind-set and technical skills.

(ii) For early-career employees, they need to gain relevant work experience and skills valued by the industry, acquire emerging skills to prepare for future development and simultanously receive salary to afford themselves. The SkillsFuture Earn and Learn Program is presumably suitable for Vietnamese context. This is a work-learn program that gives fresh graduates a head-start in careers related to their discipline of study and allows them to get a sign-on incentive of $\mathbf{\$} \$ 5,000$. In addition, SkillsFuture series which are industry-relevant training programmes on emerging skills like data analytics, digital media, cyber security, entrepreneurship, etc. will benefit Vietnamese young workers to get ready for the digitalized world of work.

(iii) For mid-career employees, they need to upskill to get promotion or reskill to transform their career. They are affected by a variety of challenges like family duties, 
ages, times, and fear of change, of trying something new and of failing, etc. Some initiatives may be useful to encourage these people to take part in upskilling and reskilling such as SkillsFuture Credit that provides an opening credit of $\mathrm{S} \$ 500$ and periodic topups for participants to pay for or offset skills related course fees, SkillsFuture Mid-Career Enhanced Subsidy for people aged 40 and above who will receive up to $90 \%$ course fee subsidy for SSG-funded courses, SkillsFuture Qualification Award that encourages workers to pursue career progression and explore new job opportunities, and SkillsFuture for Digital Workplace that aims to prepare the workforce with the digital skills and mindset to take advantage of the opportunities in the future economy.

(iv) For employers, the programs should focus on raising awareness of the importance of staff training, support them to organize on-the-job trainings, and stimulate the cooperation between companies, training institutions and the Government. SkillsFuture Earn and Learn Program, which allows employers to receive up to $S \$ 15,000$ to offset the cost of developing and providing the structured training, will be a great paradigm for Vietnam. SkillsFuture Employer Awards is another incentive for employers to recognize their efforts in investing in their employees' skills development and their advocacy for building a lifelong learning culture in their workplaces.

(v) For training institutions, their primary role is to work together with other partners to equip the workforce with a wide spectrum of relevant skills to meet the demands of the economy driven by innovation and productivity. Skills Framework is an effective tool to raise cooperation among employers, industry associations, education institutions, unions and Government. Other programs like
SkillsFuture Series and SkillsFuture Credit also contribute to boosting the involvement of training institutions in the development of skills upgrading and mastery.

These above-mentioned programs are feasible to apply to Vietnam because they will solve the challenges of disseminating lifelong learning in Vietnam. They are also compatible with the policy on workforce development in Vietnam and simultaneously complement other programs conducting in Vietnam like supporting university-business collaboration, developing high-quality vocational education and training institutions, Start-up Ecosystem, etc. in term of improving high-skilled workforce.

\section{Conclusion}

The study answered two research questions about Singaporean experience in preparing its workforce for IR 4.0 and how Vietnam can learn from such experience. Singapore is successful in making roadmaps for futureready workforce. Singapore, now, is becoming a nation of lifelong learners and a society that values skills mastery. They reimaged learning pathways for Singaporeans towards an integrated system with no dead ends. People, regardless of age or education, enjoy learning for life, love to pursue skills mastery, actively participate in skillsfuture initiatives, and contribute to moving Singapore towards an digitally advanced economy and society. This is really an impressive culture shift. Vietnam and Singapore, which are member states of ASEAN, have similar characteristics in culture, demographics and even economy, hence Vietnam should contextualize Singapore's experience to develop our workforce for the future. Within the scope of this paper, a specified approach to tomorrow's workforce preparation is suggested for 
Vietnam. They are (i) a rise in mindset, (ii) industry transformation maps to identify necessary skills for future workforce, and (iii) action programs that enable individuals to learn for life, pursue skills mastery and develop fulfilling careers.

Because many initiatives on lifelong learning and skills mastery are implementing in Singapore, the paper cannot analyze the feasibility of each of them in the context of Vietnam. It is a limit of the paper. The paper also accepts that the suggested approach is not enough to put Vietnamese existing and future workers in readiness for IR 4.0 and that experience of Singapore is just a case study, not a perfect copy for Vietnam. It is hoped that the analysis will spark off further intensive research on preparing capacities for the future workforce.

\section{References}

ASEM LLL Hub \& UNESCO Hanoi. (2010) Opening speech by H.E. Deputy Prime Minister Nguyen Thien Nhan. In the proceedings of Vietnam Forum Lifelong Learning: Building A Learning Society, Hanoi, Vietnam, pp. 25-28.

Aulbur, W., CJ, A., \& Bigghe, R. (2016), Skill Development for Industry 4.0 [Whitepaper]. Retrieved from http://www.globalskillsummit.com/ whitepaper-summary.pdf

Committee on the Future Economy. (2017). Report of the committee on the future economy, pioneers of next generation. Singapore: Government of Singapore, pp. 22-27.

Hui, C. (2016, Oct 12). 3,000 new PMET jobs with precision engineering industry roadmap: S Iswaran. Channel News Asia. Retrieved from https://www.channelnewsasia.com/news/ singapore/3-000-new-pmet-jobs-with-precisionengineering-industry-roadmap--7772958

International Labour Organization Vietnam. (2019, May 1). Future of work: Higher-skilled labour force necessary for Viet Nam's further economic development. International Labor
Organization website. Retrieved from https:// www.ilo.org/hanoi/Informationresources/ Publicinformation/comments-and-analysis/ WCMS_694938/lang--en/index.htm

International Labour Organization Vietnam. (2018). Industrial revolution (IR) 4.0 in Viet Nam: what does it mean for the labour market? [A policy brief]. Retrieved from https://www.ilo.org/wcmsp5/ groups/public/---asia/---ro-bangkok/---ilo-hanoi/ documents/publication/wcms_630854.pdf

Jain, P. \& Waqas, H. (2019). Industrial Revolution 4.0 \& its impact on policy formulation. Singapore: Blue Track Centre.

Koh, F. (2018, Mar 18). Skills vs degrees debate at ST Education Forum ends in a tie. The Straits Times. Retrieved from https://www.straitstimes. com/singapore/education/skills-v-degrees-debateat-st-education-forum-ends-in-a-tie

Kumar, P. (2004). Lifelong learning in Singapore: where are we now? International Journal of Lifelong Education 23(6), 559-568. DOI: 10.1080/026037042000311479

Leow, A. (2017, May 8). NUS opens classes to alumni as part of lifelong learning pilot [online]. The Straits Times. Retrieved from https://www. straitstimes.com/singapore/education/nus-opensclasses-to-alumni-as-part-of-lifelong-learning-pilot

Lim, A. (2019, Apr 26). S'pore can be world leader in cultivating lifelong learning: Tharman. The newpaper Singapore. Retrieved from https:// www.tnp.sg/news/singapore/spore-can-be-worldleader-cultivating-lifelong-learning-tharman

Min, C.Y. (2018, Apr 18). Singapore's 23 key industries to be grouped into 6 clusters as economy begins next phase of transformation: Heng Swee Keat. The Straits Times. Retrieved from https://www. straitstimes.com/business/economy/singapores-23key-industries-to-be-grouped-into-6-clusters-aseconomy-begins-next

Ministry of Manpower.(2014,Nov5). SkillsFuture Council Begins Work: Driving National Effort to Develop Skills for the Future. Retrieved from https:// www.mom.gov.sg/newsroom/press-releases/2014/ skillsfuture-council-begins-work-driving-nationaleffort-to-develop-skills-for-the-future 
Ministry of Trade and Industry. (2017). Integrated roadmaps to drive Industry Transformation [Media Factsheet]. Retrieved from https://www.mti.gov.sg/-/media/MTI/ITM/ General/Fact-sheet-on-Industry-TransformationMaps---revised-as-of-31-Mar-17.pdf

Pham, D.N.T. (2014). Obstacles to lifelong learning in Vietnam and some suggested solutions. VNU Journal of Education Research, Vol. 30, No. 1 (2014), 21-30.

Phung, X.N. (2018, Sep 12). Vietnam's education in the context of the Fourth Industrial Revolution. Communist Review. Retrieved from http://english.tapchicongsan.org.vn/Home/CultureSociety/2018/1147/Vietnams-education-in-thecontext-of-the-Fourth-Industrial-Revolution.aspx

Prime Minister's Office Singapore. (2018, Jan 11). The Straits Times Interview with DPM Tharman Shanmugaratnam: Social Policies, Spending and Taxes on 11 January 2018. Retrieved from https://www.pmo.gov.sg/Newsroom/straitstimes-interview-dpm-tharman-shanmugaratnam

PwC. (2018). Industry 4.0: Vietnam survey 2018. Retrieved from https://www.pwc.com/vn/en/ publications/2018/pwc-vietnam-industry-40-reporten.pdf

Seow J. (2019, Feb 11). Most trainees find SkillsFuture-funded courses helped their work: SkillsFuture Singapore. The Straits Times. Retrieved from https://www.straitstimes.com/ singapore/most-trainees-find-skillsfuture-fundedcourses-helped-their-work-skillsfuture-singapore

Shewan, D. (2017, Jan 11). Robots will destroy our jobs - and we're not ready for it. The Guardian. Retrieved from https://www.theguardian.com/ technology/2017/jan/11/robots-jobs-employeesartificial-intelligence

Sin, Y. (2017, Oct 29). Higher learning institutes to train more adults. The Straits Times. Retrieved from https://www.straitstimes.com/ singapore/education/higher-learning-institutes-totrain-more-adults

Singapore's Skillsfuture. (2016). Skillsfuture 2016 Year-in-review [Brochure]. Singapore: Author.
Singapore's Skillsfuture. (2017). Skillsfuture 2017 Year-in-review [Brochure]. Singapore: Author.

Singapore's Skillsfuture. (2018). Skillsfuture 2018 Year-in-review [Brochure]. Singapore: Author.

Singapore National Employer Federation. (2019). P-Max [Brochure]. Singapore: Author.

Tan, C. (2016). Lifelong learning through the SkillsFuture movement in Singapore: Challenges and prospects. International Journal of Lifelong Education, October 2016. DOI: 10.1080/02601370.2016.1241833, 1-14.

Teng, A. (2016, May 5). It's a fund, it's a scheme - no, it's SkillsFuture. The Straits Times. Retrieved from https://www.straitstimes.com/ opinion/its-a-fund-its-a-scheme-no-its-skillsfuture

Teng A. (2019, Mar 5). Parliament: Enterprises get new grant to cover out-of-pocket training expenses. The Straits Times. Retrieved from https:// www.straitstimes.com/politics/smes-get-newgrant-to-cover-out-of-pocket-training-expenses

Tham, Y.C. (2018a, Feb 11). Preparing workers for future economy - Work in progress: Redesigning jobs, retooling mindsets. The Straits Times. Retrieved from https://www.straitstimes.com/ singapore/redesigning-jobs-retooling-mindsets

Tham, Y.C. (2018b, Feb 11). 3 ways Singapore's approach towards training workers and redesigning jobs is changing. The Straits Times. Retrieved from https://www.straitstimes.com/politics/3-wayssingapores-approach-towards-training-workersand-redesigning-jobs-are-changing

Tharman, S. (2014). Speech by Deputy Prime Minister Tharman Shanmugaratnam. In the first meeting of the SkillsFuture Council members [speech]. Singapore.

The Adecco Group \& Tata Communications. (2019). The Global Talent Competitiveness Index: Entrepreneurial Talent and Global Competitiveness. Retrieved from https://www. insead.edu/sites/default/files/assets/dept/ globalindices/docs/GTCI-2019-Report.pdf

The National Trades Union Congress. (2017). Future jobs, skills \& training changing mindsets 
through collaborative action. Retrieved from https:// www.ntuc.org.sg/wps/wcm/connect/34808f1fe02c-42cf-b841-5df3f0d67907/FJST+Report+Ch anging + Mindsets + Through + Collaborative + Acti on $\% 281 \% 29$.pdf?MOD=AJPERES\&CACHEID= 34808f1f- e02c-42cf-b841-5df3f0d67907

The World Bank \& Vietnam Ministry of Planning and Investment. (2016). Vietnam 2035: Toward prosperity, creativity, Equity, and Democracy. Retrieved from http://vids. mpi.gov.vn/Includes/NewsDetail/12_2016/ dt_11220161028_vn2035english.pdf

The World Economic Forum \& A.T. Kearney (2018). Readiness for the Future of Production Report. Retrieved from the World Economic Forum website http://www3.weforum.org/docs/ FOP_Readiness_Report_2018.pdf

The World Economic Forum (2018). The Future of jobs report 2018. Retrieved from http:// www3.weforum.org/docs/WEF_Future_of_
Jobs_2018.pdf

UNESCO Office in Hanoi. (2011). Vietmam celebrates Lifelong Learning Week for the first time. UNESCO website. Retrieved from http:// www.unesco.org/new/en/hanoi/about-the-ha-noioffice/single-view/news/viet_nam_celebrate_ lifelong_learning_week_for_the_first_time/

Woo, J.J. (2017): Educating the developmental state: policy integration and mechanism redesign in Singapore's SkillsFuture scheme. Journal of Asian Public Policy. DOI: 10.1080/17516234.2017.1368616

Yang, C. (2017, Jan 8), 126,000 Singaporeans pick up new skills in first year of SkillsFuture Credit scheme. The Straits Times. Retrieved from https://www.straitstimes.com/singapore/ manpower/126000-singaporeans-pick-up-newskills-in-first-year-of-skillsfuture-credit 


\title{
PHÂN TÍCH KINH NGHIỆM CHUẨN BI NGUỒN NHÂN LỰC TƯO'NG LAI CỦA SINGAPORE VÀ ĐỀ XUẤT CHO VIỆT NAM
}

\author{
Nguyễn Thị Hạnh Quyên \\ Trung tâm Nghiên cúu và phát triển hội nhập khoa học và công nghệ quốc tế \\ Bộ Khoa hoc và Công nghệ \\ 39 Trần Hưng Đạo, Quận Hoàn Kiếm, Hà Nội, Việt Nam
}

Tóm tắt: Bài báo trước hết phân tích các sáng kiến của Singapore chuẩn bị nguồn nhân lực cho Cuộc cách mạng Công nghiệp lần thứ tư, sau đó kiến nghị với các nhà hoạch định chính sách Việt Nam định hướng phát triển nguồn nhân lực cho tương lai. Trong kỷ nguyên số với tốc độ thay đổi nhanh chóng, nguồn nhân lực là nhân tố then chốt để duy trì và phát triển kinh tế, do đó chiến lược phát triển của Singapore tập trung vào việc tạo ra thế hệ sẵn sàng đáp ứng yêu cầu của tương lai, góp phần tạo nên một Singapore phồn thịnh hơn. Singapore ngay từ bây giờ đã tập trung vào đào tạo nguồn nhân lực chất lượng thông qua sáng kiến học tập suốt đời và thành thạo các kỹ năng để nắm bắt cơ hội tương lai. Singapore đã làm gì để chuẩn bị cho nguồn nhân lực tương lai? Việt Nam có thể học hỏi được gì từ kinh nghiệm của Singapore? Bài báo này sẽ trả lời hai câu hỏi trên. Kết quả phân tích đã chỉ ra rằng (i) Chính phủ Singapore đã thực hiện cách thức tiếp cận vấn đề toàn diện và thành công trong xây dựng hệ sinh thái các kỹ năng cần thiết cho phát triển bền vững nguồn nhân lực và văn hóa học tập suốt đời, và (ii) Việt Nam cần suy nghĩ về chiến lược phát triển nhân lực tương lai của đất nước thông qua việc thay đổi nhận thức về học tập suốt đời, nâng cao kỹ năng, xác định rõ các kỹ năng cần thiết cho công việc tương lai, và xây dựng các chương trình hành động khuyến khích mỗi người dân học tập suốt đời, thành thạo kỹ năng và làm chủ sự nghiệp tương lai.

Tù khóa: nguồn nhân lực tương lai, học tập suốt đời, thành thạo kỹ năng, cách mạng công nghiệp lần thứ tư 